\author{
Anna Bartkowiak \\ ORCID 0000-0002-2778-6512 \\ Uniwersytet Wrocławski \\ anna.bartkowiak@uwr.edu.pl
}

\title{
Postrzeganie srebrnej gospodarki w kontekście wyzwań związanych ze starzejącą się populacją w ujęciu lokalnym. Studium przypadku
}

Artykuł nadesłany: 4.01.2020; artykuł zaakceptowany: 25.05.2020

Kody klasyfikacji JEL: H75, J11, J14

Keywords: silver ecomony, social policy, local development, ageing of the population

\begin{abstract}
Perception of the silver economy regarding challenges related to the aging population from a local perspective. Case study

An ageing society is a challenge of modern times. One of the areas where there is a chance for the effects of demographic processes to be mitigated, is the silver economy, widely understood as an economy that responds to the changing needs of different groups of older people. This aspect is evident in the development strategies being created at European, national, or regional levels, but to a much lesser extent at the local level. At the local level, actions are implemented that take into account the specificity of a particular social situation, that may differ significantly from the situation at higher levels. When drawing up development strategies, local governments and local opinion formers should have complex information of the demographic situation of a given territorial unit and should know the solutions applied in so-called good practices. The article presents the results of the research (case study) verifying whether the solutions related to an ageing population, implemented at the local level, take into account the use of the potential of the silver economy and the knowledge of local governments and opinion-formers in this respect. A qualitative study was applied, based on desk research, the technique of individual in-depth interviews and focused group interviews.
\end{abstract}




\section{Wstęp}

Wysoki trend wzrostowy ludności w wieku poprodukcyjnym oraz $50+$ jest faktem niezaprzeczalnym. Nawet jeśli prognozy długoterminowe mogą być nieco przeszacowane z powodu zakłócania przez czynnik nieznacznego odwrócenia trendu średniego czasu przeżycia, sam trend wzrostu ludności w wieku $50+$ i tak jest i będzie znaczący. Proces starzenia się społeczeństwa jest zjawiskiem, z którym muszą się zmierzyć i/lub który mogą wykorzystać zarówno środowiska biznesowe, jak i rządowe czy samorządowe, na każdym szczeblu, oraz pozarządowe. $\mathrm{Na}$ świecie coraz częściej upatruje się szans przeciwdziałania skutkom tego procesu w srebrnej gospodarce jako trzeciej co do wielkości gospodarce na świecie. Wymaga to jednak połączenia jej działań z polityką społeczną. W dokumentach strategicznych, zarówno krajowych, regionalnych, jak i lokalnych, przedstawia się działania związane ze starzejącą się populacją, jednak w marginalnym zakresie uwzględnia się potencjał srebrnej gospodarki. Efekty inicjatyw ze strony władz lokalnych można zaobserwować na przykładzie Nowej Zelandii czy Północnej Nadrenii-Westfalii, gdzie inicjatywa srebrnej gospodarki znalazła wielu entuzjastów i interesariuszy. Główną rolę odegrali w niej wprawdzie eksperci gerontologii ze środowisk naukowych, ale razem z nimi inicjatywę forsowali urzędnicy i politycy rządu krajowego oraz izby gospodarcze i stowarzyszenia producentów oraz klientów. Koncepcja oraz działania tego projektu zostały przedstawione na forum europejskim i wskazane jako dobra praktyka (Golińska, 2014, 26).

Celem artykułu jest przedstawienie wyników badań dotyczących określenia poziomu świadomości zachodzących procesów demograficznych oraz ich konsekwencji wśród osób opiniotwórczych w środowisku lokalnym, weryfikacji, jakie rozwiązania związane z tymi procesami są rzeczywiście wdrażane. Badania zostały przeprowadzone, by sprawdzić, czy istnieje świadomość wykorzystania srebrnej gospodarki jako narzędzia wspierającego w zakresie polityki społecznej i w jakich obszarach lokalnie byłoby to najbardziej możliwe.

\section{Srebrna gospodarka na poziomie lokalnym}

„Proces dostosowania miast do działania w nowych warunkach demograficznych wiąże się z szeregiem wyzwań polityki miejskiej. Społeczności lokalne powinny poszukiwać skutecznych sposobów ich wdrażania, wykorzystując nowe ścieżki rozwoju społeczno-gospodarczego. Wdrożenie nowych rozwiązań dla miast przyjaznych osobom starszym wymaga myślenia strategicznego, które wykorzystuje również szeroko rozumiany potencjał osób starszych, tj. srebrną gospodarkę" (Kubejko-Polańska, 2017, 218). Wydaje się, że obecnie ujęcie demograficznego procesu starzenia się społeczeństw jako apokaliptyczne (konieczność ponoszenia 
coraz większych kosztów) zaczyna ustępować myśleniu w stronę dostrzegania w nim szans gospodarczych.

Gordon $(2017,6)$ postrzega srebrną gospodarkę jako możliwości wynikające z wydatków publicznych i konsumenckich związanych ze starzeniem się społeczeństwa i potrzebami populacji powyżej 50. roku życia. Golińska $(2014,19)$ wskazuje, że ,pojęcie srebrnej gospodarki ma dwa znaczenia. Pierwsze, nazywane neutralnym czy opisowym, polega na ukazywaniu gospodarki ewoluującej w kierunku potrzeb starszej populacji bez jej specjalnego - interwencyjnego - ukierunkowywania. Drugie ukazuje możliwość wykorzystania starzenia się populacji do takiego ukierunkowania rozwoju, w którym zmiana struktury potrzeb ludności oraz pewien wzrost ich aktywności mogłyby stać się źródłem postępu i wzrostu gospodarczego". Takie postrzeganie srebrnej gospodarki zaczyna uwzględniać aspekty nie tylko rynkowe, lecz także związane z potencjałem społecznym. Widać więc, że gospodarka, biznes i polityka, a nawet społeczeństwo muszą dążyć w obszarze „wieku” do punktu stycznego, a nawet powinny obejmować szerszy zakres współpracy na tym polu, by wspólnie wspierać się w obliczu wyzwań nowej sytuacji demograficznej. Taka perspektywa współdziałań jest niezbędna, by móc dążyć do wspólnego zaspokojenia interesów wszystkich grup — żadna z nich nie może pozwolić sobie na potraktowanie problemów związanych ze zmianami demograficznymi jako jej niedotyczących. „Odpowiedzi na dylematy wywołane zmianami ilościowych proporcji między generacjami prowadzą do poszukiwania sposobu na modyfikację międzygeneracyjnych transferów ekonomiczno-finansowych w imię solidarności pokoleń. Główny z podejmowanych kierunków działań polega na wydłużaniu aktywności zawodowej wraz z wydłużaniem trwania życia, co nie jest wyłącznie działaniem regulacyjnym. Wymaga istotnego wysiłku w zwiększaniu tak zwanej zatrudnialności starszych zasobów pracy pod względem ich sprawności i kwalifikacji. Kierunek bardziej kompleksowy — nazwany srebrną gospodarką — polega na ukierunkowaniu podaży odpowiednio do zmieniających się potrzeb różnych grup osób starszych, aby stały się źródłem aktywizacji gospodarczej” (Golińska, 2014, 18).

Potencjał srebrnej gospodarki w obszarze srebrnego rynku towaru i usług zapewne dopasuje się do zaistniałej sytuacji demograficznej niejako samoczynnie, jednak w pozostałych obszarach (zatrudnienia, ekonomii społecznej, opieki zdrowotnej, mieszkalnym, medycznym, edukacyjnym, informacyjnym) wymaga wsparcia ze strony państwowej, zarówno rządowej, samorządowej, jak i pozarządowej (organizacje) oraz biznesowej. Światowe Forum Ekonomiczne (How 21stCentury..., 2015, 3) podkreśla, że o ile prywatny sektor wykorzystuje możliwości rynkowe, o tyle pojawia się zapotrzebowanie na strategie polityczne, które podejmą problem starzenia się społeczeństwa i umożliwią dalsze innowacje. Spostrzeżenie i zrozumienie zjawiska starzenia się społeczeństwa, następnie zareagowanie na nie poprzez wprowadzanie innowacyjnych rozwiązań będzie implikowało rozwój srebrnej gospodarki. 
Klimczuk (2013) na podstawie panelu dyskusyjnego przeprowadzonego w 2012 roku przez Forum Odpowiedzialnego Biznesu pt. „Sektor prywatny wobec wyzwań aktywnego starzenia - osoby starsze jako interesariusze firmy" wyodrębnił wyzwania wewnętrzne i zewnętrzne przedsiębiorstw wobec starzenia się społeczeństwa. Do wewnętrznych zaliczył godzenie potrzeb osób starszych z oczekiwaniami pracodawców, dostosowanie miejsca, mniej wydajna praca starszych pracowników, zmiana stanowisk wraz ze starzeniem się, dostrzeżenie doświadczenia, opóźnienie wieku emerytalnego, stereotyp wieku pracowników, konflikty międzypokoleniowe, zarządzanie wiekiem w MŚP, odmienne motywacje do pracy i aktywność różnych pokoleń, dopasowanie ofert do zmian otoczenia i nowych klientów, opracowanie sposobów docierania do osób starszych z usługami i produktami. Do zewnętrznych zaliczył natomiast przekuwanie zagrożeń w szansę i wyzwanie, walkę z negatywnymi stereotypem starości, odpowiedzialności wobec starzejącego się społeczeństwa, dostrzeżenie odmiennych nawyków i kultur poszczególnych pokoleń, zmianę zachowań i nawyków konsumenckich, przełamanie barier dotyczących starzenia się i aktywności w starości, zmianę postaw roszczeniowych i biernych na aktywne i otwarte, promocjaę dobrych praktyk, ambasadorów zmian — starszych pracowników jako osób lojalnych, doświadczonych, kontaktowych, mających dobre relacje z innymi pracownikami i klientami. Według Klimczuka (2013) „zwiększenie szans na ich pozytywne rozwiązanie wymaga uwzględnienia złożoności tych zjawisk, mechanizmów i procesów oraz przekształceń na wielu poziomach struktur społecznych i gospodarczych. Od pojedynczych gospodarstw domowych i przedsiębiorstw, poprzez ich lokalne i regionalne zrzeszenia na przykład organizacje pozarządowe, związki pracowników i pracodawców, po ich relacje ze strukturami samorządowej i rządowej administracji publicznej. Zasadne jest uwzględnianie kontaktów tych podmiotów z zagranicznymi organizacjami i wymiana dobrych praktyk".

$\mathrm{Na}$ poziomie od europejskiego poprzez krajowy do wojewódzkiego istnieją dokumenty i strategie rozwoju obejmujące obszar wyzwań związanych ze zmianami demograficznymi, stworzone przy współpracy zespołów ekspertów. Natomiast na poziomie lokalnym, co potwierdzają badania Kubejko-Polańskiej (2017), tworzy się strategie często odwzorowujące rozwiązania z wyższych poziomów, nie do końca uwzględniając specyfikę danej sytuacji lokalnej; aspekt zaspokajania potrzeb $\mathrm{w}$ wymiarze społecznym jest w nich bardziej identyfikowalny, natomiast aspekt ekonomiczny srebrnej gospodarki w wielu przypadkach jest ignorowany lub znacznie marginalizowany. W celu zapewnienia trwałego rozwoju społeczno-gospodarczego niezbędne jest uwzględnianie działań strategicznych w obu tych obszarach. Rozwiązania dotyczące strategii przeciwdziałania starzeniu się społeczeństwa na poziomie lokalnym muszą być spójne ze strategiami europejskimi, krajowymi czy nawet wojewódzkimi, ale nie mogą zostać „przekalkowane” bezpośrednio na poziom lokalny, gdyż charakterystyka struktur demograficznych jest odmienna. „Zasadnicze działania w ramach koncepcji srebrnej gospodarki podejmowane 
są bowiem lokalnie. W sytuacji, w której szczebel regionalny ma słabe narzędzia bezpośredniego oddziaływania na szczeble lokalne, tak jak to ma miejsce w Polsce, niezbędne jest rozważenie wszelkich sposobów wpływania na decyzje lokalne w zgodzie z regionalną koncepcją srebrnej gospodarki” (Golińska, 2014, 25). Tym bardziej więc możliwość wykorzystania potencjału srebrnej gospodarki w przeciwdziałaniu negatywnym skutkom procesów starzenia się społeczeństwa na poziomie lokalnym wymaga rozumienia jej istoty przez osoby znaczące dla tworzenia rozwoju lokalnego: ,koncepcja srebrnej gospodarki to koncepcja przenikająca tradycyjnie klasyfikowane sektory; to wymiar, który powinien być widoczny w każdym działaniu: infrastrukturalnym, transportowym, komunikacyjnym, wspierania przedsiębiorczości, rozwoju kapitału ludzkiego i zdrowia, w polityce publicznej. Wpisanie jej do tzw. polityki senioralnej usytuowanej zwykle w obszarze pomocy społecznej spowoduje, że będzie stanowić raczej niszę działalności socjalnej niż niezbędny kierunek rozwoju regionalnego" (Golińska, 2014, 27).

\section{Metodologia badań}

W celu zgłębienia zagadnienia wspierania strategii polityki społecznej związanej z procesem starzenia się społeczności srebrną gospodarką poprzez rozszerzenie dotychczasowych badań na poziom lokalny i określenie ich dalszych kierunków przyjęto podejście heurystyczne oraz jako metodę badawczą zastosowano studium przypadku. Jako przypadek uwzględniono miasto Leszno, albowiem jest to dawne miasto wojewódzkie, średniej wielkości i jednocześnie „starzejące” się szybciej niż Polska (roczny przyrost udziału ludności w wieku poprodukcyjnym w ogóle ludności ${ }^{1}$ dla Polski wynosi 0,58 p.p., a dla Leszna 0,81 p.p. (ostatnie pięć lat nawet 0,86 p.p.) oraz jest jednym z najszybciej starzejących się miast województwa wielkopolskiego. Miasto Leszno jest znacznie ,starsze” demograficznie niż gminy wchodzące w skład powiatu leszczyńskiego. Od 2014 roku odsetek mieszkańców w wieku poprodukcyjnym jest większy niż w wieku przedprodukcyjnym. Leszno zalicza się do grupy powiatów o wysokim wskaźniku obciążenia demograficznego. Ponadto ma wiele dokumentów strategicznych. Na terenie miasta działa także znacząca liczba organizacji pozarządowych ukierunowanych na osoby starsze.

Specyfika demograficzna przejawia się w tym, że ogólna liczba ludność utrzymuje się na względnie stałym poziomie, a poprodukcyjna przyrasta mocno nie tylko z uwagi na przedłużającą się średnią życia, ale także, bardzo widoczny w Lesznie, odpływ ludzi w wieku produkcyjnym.

1 Według linii trendu wyznaczonej na podstawie frakcji ludności w wieku poprodukcyjnym w ludności ogółem (obliczenia własne), a nie według prognoz GUS z uwagi na większy błąd ex post dla prognoz GUS względem prognoz na podstawie trendu liniowego. Nieznacznie lepsze dopasowanie $(\mathrm{o} 0,003)$ wskazuje trend dwumianowy, ale przy uwzględnieniu danych z ostatnich pięciu lat (gdy obserwuje się tendencje trendu do przejścia w liniowy) przy trendzie liniowym otrzymuje się jednak mniejszy błąd ex post. 


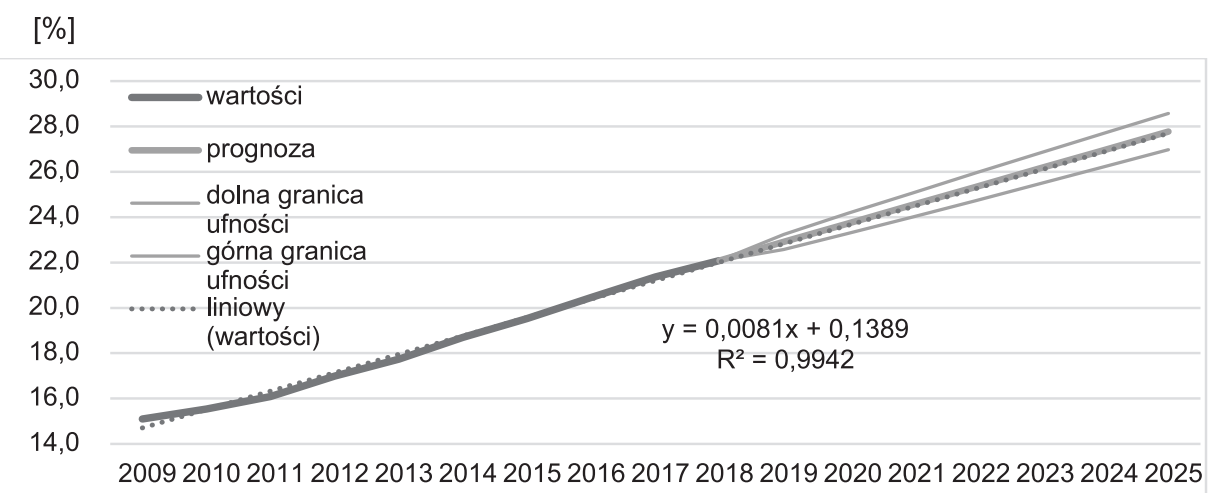

Rysunek 1. Odsetek ludności w wieku poprodukcyjnym w ogóle mieszkańców Leszna

Źródło: opracowanie własne na podstawie Broszury Urzędu Miasta Leszna...

W Lesznie już w 2022 roku co czwarta osoba będzie w wieku poprodukcyjnym, natomiast w Polsce nastąpi to dwa lata później. W mieście o takiej specyfice jeszcze bardziej istotne jest wczesne podjęcie działań związanych z przeciwdziałaniem skutkom starzejącej się populacji, by nie doprowadzić do konieczności mierzenia się z zastanymi problemami ekonomicznymi i społecznymi z tym związanymi. Konieczne jest dostosowanie rozwiązań do specyfiki lokalnej, a to wymaga także rozumienia pojęcia srebrnej gospodarki postrzeganej zarówno jako całokształt działań związanych z wykorzystaniem potencjału starzejącego się społeczeństwa, jak i jej stanu w danym podregionie oraz świadomości lokalnych problemów z tym związanych.

W celu zbadania tego aspektu wykorzystano dyrektywę metodologiczną postulującą zastosowanie wywiadów pogłębionych w początkowej fazie prowadzenia badań. W tym przypadku wywiady pogłębione realizują cel eksploracyjny, gdy problematyka badawcza dotyczy zjawisk dotychczas nieprzebadanych lub słabo poznanych. Wykorzystanie IDI w funkcji zwiadu badawczego służy weryfikacji problematyki badawczej — określeniu, czy problem/zjawisko występuje — zanim zostaną zaangażowane duże środki (czas, pieniądze, zasoby ludzkie) (Miński, 2017, 37). W fazie wstępnej, wykorzystanej do dalszej realizacji badań jakościowych, które w rezultacie sumarycznie staną się podstawą także badań ilościowych, przeprowadzono badanie jakościowe wykonane techniką indywidualnego wywiadu pogłębionego (IDI) zogniskowanego (na podstawie scenariusza) z 10 osobami znaczącymi w Lesznie (dobranymi celowo) ze środowiska JTS, NGO, związanymi z obszarem dotyczącym seniorów oraz dużego przedsiębiorstwa o zasięgu międzynarodowym (w celu rozszerzenia aspektu badań o perspektywę lokalno-globalną). W celu triangulacji badań przeprowadzono kolejny etap: badanie jakościowe wykonane techniką zogniskowanego wywiadu grupowego 
(FGI), gdyż technika ta według Babbie $(2008,346)$ często ujawnia takie aspekty tematu, których badacz by nie przewidział i które nie pojawilyby się w wywiadach z jednostkami. Do badania tego dobrano w sposób celowy ośmiu respondentów (osoby znaczące wskazane przez konsultantów lokalnych) ze środowiska organizacji pozarządowych, przedsiębiorców, polityków oraz osób starszych aktywnie uczestniczących w życiu społecznym. Wyniki i wnioski z desk research stanowią podstawę formułowania pytań wykorzystanych w scenariuszu IDI, a rozbieżności między stanem faktycznym a opiniami i ocenami kluczowych informatorów pozwalają wypracować rekomendacje dyskutowane z kolei w trakcie panelu ekspertów (Miński, 2017, 49). Kwestionariusz wywiadów IDI utworzony był w oparciu o analizę materiałów zastanych (desk research) — na podstawie katalogu dokumentów strategicznych wskazanych przez konsultantów lokalnych — pracowników JTS. Analiza treści dokumentów była realizowana na podstawie listy poszukiwanych informacji wynikających z tematu niniejszego artykułu. Scenariusz wywiadu pogłębionego FGI oparto na kwestionariuszu IDI oraz informacjach pozyskanych z pierwszej części badań, które wskazywały obszary do pogłębienia badań. Oba badania były poufne.

\section{Główne wyniki}

\subsection{Analiza treści, materiałów zastanych}

Wszystkie dokumenty strategiczne dotyczące miasta Leszna wskazują na problem związany ze starzeniem się społeczeństwa oraz na inne problemy z tego wynikające, takie jak koszty związane z pomocą społeczną, spadek dochodów mieszkańców, skala ubóstwa, wykluczenie społeczne, a także dotyczące rynku pracy.

Strategie lokalne odnoszą się do strategii globalnych, jak Rządowy Program na Rzecz Aktywności Społecznej Osób Starszych na lata 2014-2020, Strategie działania w starzejącym się społeczeństwie czy Zaktualizowana strategia rozwoju województwa wielkopolskiego do 2020 roku wraz z Wielkopolskim Programem na Rzecz Osób Starszych do roku 2020, które uwzględniają aspekt srebrnej gospodarki. Zadaniem tej gospodarki ma być sprostanie potrzebom i oczekiwaniom osób starszych poprzez stworzenie produktów i usług skierowanych do tej grupy osób oraz zatrudnianie osób starszych i planowanie przestrzenne uwzględniające ich potrzeby i zmieniające się możliwości.

W Strategii rozwoju społeczno-gospodarczego obszaru funkcjonalnego aglomeracji leszczyńskiej (OFAL) do 2030 roku w części opisującej demografię wyraźnie podkreślono, na podstawie wskaźników obciążenia demograficznego oraz prognoz ludności, że najbardziej obciążone ludnością w wieku poprodukcyjnym w powiecie leszczyńskim jest miasto Leszno — prognozy w tym zakresie wskazują na dynamiczne pogłębianie się zjawiska starzenia się populacji tego miasta. 
Analiza SWOT sfery społecznej wskazuje na obszar związany z osobami starszymi w kategorii „słaba strona”: brakuje odpowiedniej oferty usług skierowanych do seniorów, w kategorii „,szansa”: rozwój wolontariatu (zwłaszcza wśród seniorów), jako „zagrożenie”: procesy demograficzne — starzenie się społeczeństwa. Analiza SWOT sfery gospodarczej w żadnym obszarze nie uwzględnia srebrnej gospodarki. Po analizie i diagnozie sytuacji OFAL działania związane ze zmianami demograficznymi uwzględnione zostały w Przedsięwzięciu 2.1.1 Podejmowanie działań dostosowawczych w polityce społecznej w kontekście starzenia się społeczeństwa dotyczącym między innymi:

1. budowy i funkcjonowania sieci domów dziennego pobytu dla seniorów i osób niepełnosprawnych,

2. sieci mobilnych usług opiekuńczych dla osób starszych i niepełnosprawnych,

3. aktywizacji seniorów (UTW, ośrodki kultury).

Działania te koncentrują się głównie na aspektach opiekuńczo-medycznych oraz edukacyjno-kulturalnych, nie uwzględniają aktywizacji w obszarze zawodowym oraz działań związanych z gospodarką ukierunkowaną na osoby starsze.

Strategia rozwiązywania problemów społecznych dla miasta Leszna na lata 2017-2023 w dwu z trzech postawionych wyzwań uwzględnia starzejące się społeczeństwo: „Społeczeństwo Leszna się starzeje. Zjawisko to będzie się nasilać w ciągu najbliższych lat” oraz „W związku z postępującymi procesami starzenia się społeczeństwa konieczne jest podejmowanie działań na rzecz integracji i pomocy społecznej dla osób w wieku senioralnym oraz osób niepełnosprawnych". W części dotyczącej potencjału wskazuje: „W Lesznie obserwowana jest rosnąca aktywność organizacji społecznych, w szczególności działających na rzecz środowisk senioralnych i osób niepełnosprawnych. Wzrasta również aktywność i świadomość środowisk senioralnych". W dokumencie tym rosnącą liczbę osób w wieku poprodukcyjnym określono jako nowy wymiar ubóstwa. Autorzy strategii zauważają także przez lata 2012-2016 wzrost udziału osób w wieku 55+ w ogóle bezrobotnych (z 12,2\% do 19\%). Widać więc, że frakcję osób dorosłych niepracujących, poza mieszkańcami w wieku poprodukcyjnym, wyraźnie zasila także grupa osób niepracujących w wieku 55+. Jednym z celów strategii rozwiązywania problemów społecznych jest wspieranie aktywności seniorów realizowane poprzez następujące działania:

1. analizowanie sposobu funkcjonowania osób starszych poza środowiskiem rodzinnym,

2. szeroka integracja osób starszych ze środowiskiem lokalnym (szkoły, placówki kulturalne),

3. integracja i edukacja seniorów,

4. rozwój placówek wsparcia dziennego, w tym rozwój i poprawa stanu infrastruktury tych placówek. 
Jednak w formułowaniu celu: Aktywizacja zawodowa oraz wspieranie rozwoju przedsiębiorczości, mimo wcześniej zdiagnozowanych potrzeb, nie uwzględniono wyodrębnionych działań związanych ze zjawiskiem rosnącej grupy osób w wieku poprodukcyjnym (nowym wymiarem ubóstwa).

Dopełnieniem Strategii rozwiązywania problemów społecznych dla miasta Leszna jest Miejska strategia rozwiązywania problemów osób starszych „Seniorzy w Lesznie" 2014-2020, która według jej autorów została pomyślana i skonstruowana jako narzędzie efektywnego zarządzania przyszłością osób starszych w mieście. W Strategii tej w części Odniesienie do istniejących dokumentów wielokrotnie podkreślono występowanie i uwzględnianie w nadrzędnych dokumentach idei srebrnej gospodarki, lecz w samym dokumencie jej nie uwzględniono. Wśród sześciu wyodrębnionych celów strategicznych tylko w Aktywność i zainteresowania - uczestnictwo w kulturze, rozrywka, sport, rekreacja, turystyka, hobby, życie towarzyskie ujęto aspekt gospodarczy: Pełnoprawny udział osób starszych w życiu politycznym i gospodarczym, jednak nie miał on odzwierciedlenia ani w wymienionych zadaniach realizowanych, ani w zamierzonych.

Ponadto na terenie miasta Leszna funkcjonują programy adresowane do seniorów, które wymieniane były przez respondentów podczas badań: Leszczyńska Karta Seniora (dla osób 65+, obejmuje zniżki na niektóre usługi i towary podmiotów, które przystąpiły do programu), Rehabilitacja Seniorów (dla osób 60+ z dysfunkcją narządów) oraz Złota Rączka (dla osób 65+ spełniających określone kryterium dochodowe).

Badanie przeprowadzono w końcowym okresie funkcjonowania Miejskiej strategii rozwiązywania problemów osób starszych oraz w trakcie trwania Strategii rozwoju społeczno-gospodarczego OFAL uwzględniającej obszar starzenia się społeczeństwa, a także po widocznych (dla zainteresowanych) różnych debatach publicznych i publikacjach dotyczących tej sfery. Spodziewano się więc, że pojęcia z tym połączone nie powinny stanowić zupełnego novum dla osób związanych z jej realizacją oraz innych osób opiniotwórczych w środowisku lokalnym.

\subsection{Analiza indywidualnych wywiadów pogłębionych (IDI)}

\subsubsection{Potrzeby, oczekiwania i problemy seniorów w Lesznie}

Do najważniejszych potrzeb, oczekiwań i problemów seniorów w Lesznie badani zaliczyli: brak miejsc w domach pomocy społecznej, rosnące zapotrzebowanie na usługi opiekuńcze przy jednoczesnym braku odpowiednich kadr, problem z dostępem do usług medycznych (na przykład brakuje geriatrów), brak usługi „,wytchnieniowej" (dla osób na stałe zajmujących się seniorem zależnym), problemy komunikacyjne, to jest brak odpowiednio umiejscowionych przystanków, ,istnienie osób, których budżet nie wystarcza na odzież, dobry wygląd i takie osoby zamykają się w domu, nie chcą być aktywne, wstydzą się". Kilkoro respondentów 
podkreślało, że ,jeśli spełnione są warunki bytowe, to tego czego na pewno tym osobom brakuje, to jest towarzystwa, kogoś do rozmowy", ,jak zapewni im się podstawowe potrzeby to częściej i chętniej aktywizują się. Wtedy potrzebują być dostrzeganym, chcą »smakować życia«, potrzebują rozrywki i edukacji”.

Wszyscy respondenci zaznaczali, że potrzeby i oczekiwania osób starszych są bardzo zróżnicowane, że nie jest to grupa jednorodna. Wyodrębniano podziały ze względu na wiek, płeć, zasoby finansowe, stan zdrowia, aktywność, chęć działania, uczestnictwa w różnych propozycjach, posiadania angażującej się rodziny oraz najbardziej różnicujący czynnik, czyli status bycia zależnym lub niezależnym. „Część osób poświęca się rodzinie, wnukom i to im wystarcza, część osób choruje i jest zależna, ale część osób jest aktywna. Zamyka się im aktywność zawodowa, znajomości z nią związane i powstaje przestrzeń, z którą nie wiadomo, co zrobić i te osoby szukają organizacji dla seniorów. Skończyły się ich działania, ale nie skończyła się ich energia, często tracą też drugą połowę i szukają zajęć dla siebie".

Organizacje zgłaszały też problem z nakłonieniem niektórych osób do aktywności, do zaangażowania się w różne inicjatywy. W wielu wypowiedziach zwracano także uwagę, że młodsi seniorzy są bardziej roszczeniowi, mniej chcą się udzielać społecznie.

\subsubsection{Działania podejmowane przez miasto oraz konsultacje społeczne}

Działania podejmowane przez miasto w związku ze starzeniem się ludności, wymieniane przez badanych, to Program Rehabilitacji Seniorów, Teleopieka senioralna (do wzywania pomocy w chwilach zagrożenia życia; małe zainteresowanie, respondent, który bezpośrednio odpowiada za ten program uważa, że powodem jest strach przed technologiami), programy zdrowotne (na przykład wykrywanie WZW typu C, boreliozy), kluby seniora, Dom Seniora, Leszczyńska Rada Seniorów (LRS), Karta Seniora (lecz „daje ona mało udogodnień, jest mało popularna"), program Złota Rączka, pozbywanie się barier architektonicznych w niektórych miejscach, wydarzenia jak senioriada, wakacje seniora w Lesznie, czytanie prasy. Miasto wspiera finansowo organizacje pozarządowe zajmujące się kwestiami osób starszych (,,i tu skupia się znaczna część realizowania polityki senioralnej”). Według niektórych respondentów miasto głównie opiera się na wolontariuszach i NGO-sach, wielu też uważa, że w Lesznie brakuje skoordynowania działań na rzecz osób starszych. Respondent z UM Leszna twierdzi, że prezydent jest bardzo dobrze poinformowany o sytuacji seniorów i stara się reagować na pojawiające się problemy w tym zakresie. Według innych respondentów miasto zdaje sobie sprawę, ale niewystarczająco działa w zakresie zapobiegania problemów związanych ze starzejącą się populacją miasta. Urząd Miasta ma w planie utworzenia Leszczyńskiego Centrum Usług Senioralnych, którego główne zadania mają się koncentrować wokół spraw opiekuńczo-medycznych. 
W kwestii prowadzenia przez placówki miejskie konsultacji z seniorami na temat ich potrzeb i oczekiwań według pracownika Urzędu Miasta zagwarantowano odpowiednią reprezentacyjność różnych grup społecznych w LRS i pełni ona też dyżury, „także można domniemywać, że mamy obraz pełnego środowiska senioralnego". Niektórzy respondenci zgłaszają, że brakuje ankietyzacji potrzeb, sytuacji bytowej, materialnej, zdrowotnej osób starszych. Miasto zgłasza się do organizacji pozarządowych z prośbą o konsultacje dokumentów strategicznych, jednak nie w celu zdiagnozowania potrzeb i oczekiwań wśród osób starszych. Władze miasta są przychylne działaniom na rzecz seniorów, jednocześnie „urzędnicy, ustanawiając pewne rzeczy dla seniorów, nie pytają ich specjalnie o zdanie"; „Rada Seniorów raczej inicjuje i prosi o informacje Urząd Miasta, ale oni sami nie inicjują w drugą stronę zdobywania informacji od seniorów".

Respondenci przedstawiali swoje spostrzeżenia, że uczestnictwo w klubach, działaniach organizowanych na rzecz seniorów spowalnia proces starzenia się w sensie psychofizycznym oraz że działania na rzecz łagodnego wychodzenia $\mathrm{z}$ rynku pracy byłyby korzystne i potrzebne.

\subsubsection{Srebrna gospodarka}

Połowa respondentów nie znała wcześniej pojęcia „srebrna gospodarka”. Reprezentant Urzędu Miasta potrafił jednak doskonale określić, na czym ona polega: ,jest to reagowanie przedsiębiorców czy też rynku ogólnodostępnych usług na potrzeby seniorów, dostosowane do zmieniającej się struktury społeczeństwa”, „od biznesu standardowych odróżnia ją nietraktowanie seniora standardowo, tylko zrozumienie jego potrzeb przy jego uszczuplonym portfelu czy przygotowanie pewnej oferty dla seniorów". Samorząd współpracuje z podmiotami gospodarki społecznej i respondenci wskazują, że takie podmioty mają wsparcie ze strony miasta.

Z informacji od badanych wynika, że leszczyńscy przedsiębiorcy jeszcze nie wykazują zainteresowania srebrną gospodarką, według nich wymaga to „czasu, współpracy i chęci zarówno ze strony emerytów, którzy muszą chcieć być aktywnymi zawodowo, z drugiej strony musi być też zachęta, by ich utrzymać na rynku pracy oraz uaktualnianie dostępności usług i towarów do seniorów". Przedsiębiorcy nie zgłaszają się do seniorów w celu na przykład testowania różnych produktów, jeszcze nie dostrzegają realnych potrzeb tej grupy. „Mówi się o tym [srebrna gospodarka], ale w praktyce jeszcze tego nie widać”. Jedna z respondentek wskazała na rozwijające się w Lesznie usługi turystyczne skierowane do osób starszych. Podkreślała ona, że rosną też oczekiwania tej grupy klientów związane ze zwiększającą się ich zamożnością. Zdarzają się incydentalne usługi kulturalne kierowane do osób starszych. Coraz więcej osób z tej grupy wiekowej akceptuje też odpłatne usługi rekreacyjne.

Respondenci, nawet ci, którzy wcześniej nie spotkali się z pojęciem srebrnej gospodarki, uważają, że jest to „ciekawy obszar do zagospodarowania”, widzą możliwości wykorzystania wiedzy seniorów w kształceniu młodych osób w za- 
kresie umiejętności, które przydają się w życiu codziennym czy zawodowym (w tym kwestii zanikających zawodów, wskazówek wynikających z doświadczenia, mentoring). Do organizacji pozarządowych zgłaszają się seniorzy z prośbą o pomoc w znalezieniu zatrudnienia, mają też potrzebę, by ich wiedza była spożytkowana. Respondenci widzą możliwość i potrzebę zatrudnienia ich, ale według nich pracodawcy wolą młodszych: „Staż dla seniora byłby bardzo potrzebny, oni są ciekawi [...], są bardziej otwarci na nowe niż 30-, 40-latkowie, [...] ale będą opory przedsiębiorców do zatrudnienia stażystów, chyba że będzie jakieś zewnętrzne wsparcie".

Respondentka $\mathrm{z}$ dużego przedsiębiorstwa nie obserwuje aktualnie problemów związanych z rekrutacją pracowników w swojej firmie, ale wedle jej wiedzy takie problemy występują w innych dużych firmach. Zauważa jednak wzrost średniej wieku pracowników w jej firmie — z uwagi na specyfikę branży (predyspozycje fizyczne) większość pracowników nie może już pracować powyżej 60. roku życia. W tej chwili starzejący się pracownicy nie są zjawiskiem priorytetowym, ale zarządzający powoli się do tego przygotowują: jeden kierunek to zwiększanie zaangażowania technologii w procesie produkcyjnym, a drugi to przygotowywanie starszych pracowników, dysponujących największą wiedzą i takich, którzy będą chcieli takich zmian, do bycia szkoleniowcami, mentorami. W firmie tej kładzie się też nacisk na łączenie doświadczenia starszych pracowników z umiejętnością obsługi i otwartością na nowe technologie młodszych pracowników. Być może w przyszłości zastosują także mentoring odwrócony. Według respondentki firmy, które nie będą się przygotowywały do zmian wynikających z procesu starzenia się, wypadną z rynku.

Badani nie kojarzą żadnych lokalnych przedsiębiorców świadczących usługi dla osób starszych, wskazują przykładowe możliwości dla przedsiębiorców, takie jak inicjatywy dla seniorów w kawiarniach, transport z pomocą przy noszeniu bagażu na przykład do sanatorium czy szpitala, firma organizująca przysyłanie sprawdzonych przez nich fachowców (malarz, hydraulik, osoba do sprzątania, koszenia trawy itp.), usługi fryzjerskie, kosmetyczne, sklepy odzieżowe dla seniorów. Dwie osoby badane twierdzą, że szybciej do seniorów trafią sami seniorzy i może to oni powinni wprowadzać idee z zakresu srebrnej gospodarki. Jedna z badanych uważa, że „biznes jak znajdzie niszę, to sam będzie w nią wchodził, rynek sam się dostosuje do zapotrzebowania”. Niektórzy respondenci wskazywali, że Karta Seniora (zniżki zachęcające do korzystania z rynku usług i towarów, lecz niestety mało podmiotów przystąpiło do współpracy w jej ramach) jest pewną formą srebrnej gospodarki.

Badane osoby opiniotwórcze uważają, że środowisko lokalne byłoby gotowe wspierać inicjatywy związane ze srebrną gospodarką oraz że mogłaby ona być elementem leszczyńskiej polityki społecznej, gdyż sama nie da rady sprostać kwestiom związanym ze starzeniem się społeczeństwa. 


\subsection{Analiza wywiadu grupowego zogniskowanego (FGl)}

Uczestnicy wywiadu potwierdzają, że miasto jest bardzo otwarte na działania dotyczące seniorów, na organizacje pozarządowe zajmujące się tym obszarem. Natomiast część organizacji współpracuje z sobą, a część w ogóle tego nie robi, co respondenci uważają za problem. Brakuje świadomości, że seniorzy są pewną siłą napędową gospodarki (na przykład „opiekunki osób starszych czy produkcja balkoników, którą będą przecież robili młodzi ludzie i tak mnóstwo różnych rzeczy"). Badani podkreślają, że należy też zmieniać mentalność ludzi młodych w kierunku zmian społecznych i srebrnej gospodarki. Przedsiębiorcy nie postrzegają zagrożeń i potencjału w starzejącym się społeczeństwie.

Respondenci uważają, że nie ma potrzeby tworzenia systemowej rekwalifikacji zawodowej seniorów: ,jeśli są indywidualne przypadki, to one to sobie organizują bez problemu same". Potwierdzają także, że nie obserwuje się w Lesznie wysyłania pracowników na wcześniejsze emerytury.

Wszyscy badani dostrzegają potencjał w srebrnej gospodarce: „Świat idzie w taką stronę, żeby nadążyć za nowymi technologiami, to seniorzy także muszą się uczyć i gdyby nie było działań na rzecz seniorów, nie byłoby takiej możliwości”; ,potrzebne są też usługi z zakresu opieki, także dla osób starszych, które mają w domu osoby jeszcze starsze ciężko chore i nie wiedzą jak się nimi zając". Jednogłośnie także stwierdzają, że państwo powinno stworzyć instytucje kształcenia ustawicznego. Szanse srebrnej gospodarki upatrują także w działaniach takich, jak praca seniorów w zakresie opieki nad dziećmi (niekoniecznie własnymi wnukami), opieki nad osobami chorymi neurologicznie czy psychicznie, rehabilitacja osób starszych, turystyka senioralna, usługi fryzjerskie, kosmetyczne oraz moda przeznaczona dla seniorów.

Badani uważają, że istotnym elementem wpływającym na podnoszenie jakości życia osób starszych jest „aktywność”, ,wychodzenie do ludzi”, ,poczucie bycia potrzebnym”; „osoby, które zostają w domu, izolują się, stają się zupełnie innym człowiekiem”. Widzą też potrzebę organizowania akcji w stylu „Ruszaj się”; „mieszkańcy jakby sami też nakręcają się nawzajem, inicjują aktywność i pociągają tym innych". Osoby przechodzące na emeryturę często potrzebują i chcą być aktywne, także zawodowo, ale przedsiębiorcy ich nie rekrutują. Jeden z respondentów twierdzi, że istotnym czynnikiem tej sytuacji są duże koszty utrzymania pracownika w Polsce. Inny z badanych spotykał się także z przypadkami, że „po przejściu na emeryturę szukają pracy dla siebie nawet za »dziękuję«". Jednak badani stwierdzali, że „,przedsiębiorca musi mieć naturalną potrzebę, nie można go przymusić do zatrudnienia seniorów”.

Na pytanie „Co jest korzystniejsze w Lesznie: czy srebrna gospodarka koncentrująca się na promowaniu i wspieraniu aktywności ekonomicznej, zatrudnianiu osób starszych czy tylko na usługach i produktach kierowanych do tej grupy wiekowej?" większość badanych wskazała drugi wariant i tylko jedna osoba 
pierwszy. Jedna z badanych zauważyła, że także na ogólnopolskich targach dla seniorów widoczne są tylko usługi i towary. Jednogłośnie respondenci stwierdzają natomiast, że srebrna gospodarka jest w Lesznie potrzebna. Uczestnicy wywiadu grupowego mieli także za zadanie wykonać analizę SWOT dla Leszna z punktu widzenia rozwoju srebrnej gospodarki. Wyniki tej analizy przedstawia tabela 1 .

Tabela 1. Analiza SWOT rozwoju srebrnej gospodarki w Lesznie sporządzona przez badanych biorących udział w FGI

\begin{tabular}{|c|c|}
\hline Mocne strony & Słabe strony \\
\hline $\begin{array}{l}\text { — aktywność osób starszych } \\
\text { — potencjał seniora } \\
\text { — pozytywny wizerunek seniora } \\
\text { — liczebność seniorów } \\
\text { — przedsiębiorcy chętnie wspomagają finanso- } \\
\text { wo NGO-sy zajmujące się seniorami } \\
\text { — duża liczba przedsiębiorców } \\
\text { - zapotrzebowanie na usługi rehabilitacyjne } \\
\text { — zainteresowanie rozrywką, rekreacją, } \\
\text { kulturą }\end{array}$ & $\begin{array}{l}\text { — zamożność seniorów } \\
\text { — roszczeniowość seniorów } \\
\text { — większzy nacisk w stronę osób zależnych } \\
\text { — niechęć do zatrudniania seniorów } \\
\text { — niedostrzeganie przez przedsiębiorców } \\
\text { zagrożeń i potencjału starzejącego się społe- } \\
\text { czeństwa }\end{array}$ \\
\hline Szanse & Zagrożenia \\
\hline $\begin{array}{l}\text { - ekonomia społeczna } \\
\text { — dotacje/programy zewnętrzne } \\
\text { - czas wolny seniorów } \\
\text { — potencjał doświadczenia zawodowego doj- } \\
\text { rzałych pracowników } \\
\text { — spowalnianie i wydłużanie procesu starzenia }\end{array}$ & $\begin{array}{l}\text { — polityka senioralna nie uwzględnia zróżni- } \\
\text { cowania wewnętrznego wśród seniorów } \\
\text { — wysokie koszty pracy } \\
\text { — nisza rehabilitacyjna (za mało usług i kadr) } \\
\text { stereotypy dotyczące starości }\end{array}$ \\
\hline
\end{tabular}

Źródło: opracowanie własne na podstawie analizy SWOT wykonanej przez uczestników badania.

Jako korzyści z wprowadzenia srebrnej gospodarki badani widzą spowolnienie procesu starzenia, wzrost zasobności portfela seniora, poprawę zdrowia, zagospodarowanie czasu wolnego seniorów, poprawę kondycji psychofizycznej.

Respondenci uważają, że tworzenie srebrnej gospodarki w Lesznie powinno się zacząć od wykorzystania potencjału seniorów, „uświadamiając im pewne sprawy, bo im się chce chcieć, a to pociągnie Leszno". Niezbędne jest też współdziałanie między seniorami a przedsiębiorcami, jednak „musi być ktoś, kto to połączy" i najlepiej byłoby, gdyby miasto zainicjowało taką współpracę w zakresie funkcjonowania srebrnej gospodarki, przed uprzednim rozpoznaniem i zdiagnozowaniem problemu w tym zakresie.

\section{Wnioski}

Z badań wynika, że osoby opiniotwórcze w środowisku lokalnym, nawet te, które wcześniej nie spotkały się z pojęciem srebrnej gospodarki, uważają, że może ona 
być szansą i wsparciem w niwelowaniu skutków zachodzących procesów demograficznych miasta, lecz wymaga to impulsu ze strony samorządowców. Obecnie w zakresie działań związanych ze starzejącą się populacją wyłania się obraz bardzo wspierających, lecz niewychodzących z inicjatywą włodarzy Leszna. Obserwuje się jednokierunkowość działań samorządowców, którzy chętnie reagują na potrzeby organizacji zajmujących się seniorami, ale sami nie wychodzą z propozycjami czy chęciami zdobycia informacji w tym zakresie, jak gdyby przyjęli, że inicjatywy oddolne są wyczerpujące w zakresie zgłaszania zapotrzebowania w tym obszarze i nie potrzeba działań odgórnych. Jednak według badanych NGO-sy nie są w stanie zainicjować skutecznych działań biznesu w zakresie srebrnej gospodarki i nie uznają, aby to była ich misja, uważając, że powinność ta leży po stronie włodarzy, których chętnie wesprą. Respondentka z dużej firmy twierdzi, że jeśli przedsiębiorcy otrzymają odpowiednie statystyki, prognozy (lub sami do nich dotrą), wtedy pochylają się nad danymi zjawiskami i szukają rozwiązań. Raport CEDEFOP (za: Raport MRR i OECD 2013, 138) sugeruje, że „Polityki i działania publiczne [...] skierowane do przedsiębiorstw, byłyby bardziej skuteczne, gdyby położono większy nacisk na popularyzację wiedzy o przemianach demograficznych wśród pracodawców. Umożliwiłoby to przedsiębiorstwom podjęcie działań opartych na wiarygodnych danych i opracowywanie lub rozwijanie systemów zarządzania zasobami ludzkimi, uwzględniających potrzeby starszych pracowników". Otwieranie się na dobre praktyki związane z zarządzaniem wiekiem będzie koniecznością, a nie tylko dobrym przykładem CSR, a CSR może być narzędziem w tym zakresie. Może to być zatem przestrzeń współpracy między biznesem a samorządem. Biznes, gdy dostrzeże korzyści, dostosuje się do zapotrzebowania na rynku, natomiast obserwuje się większą potrzebę pobudzenia, w zakresie srebrnej gospodarki, lokalnej polityki społecznej, dla której otoczenie biznesowe byłoby wsparciem w zarządzaniu problemami związanymi z sytuacją demograficzną i generowanymi przez nią kosztami. Na niereagowanie rynku prywatnego zapewne nakłada się sprzyjająca koniunktura gospodarcza i niskie bezrobocie, które powoduje niwelowanie konsekwencji zmian demograficznych, jednak gdy trend gospodarczy na rynku pracy odwróci się, wówczas konsekwencje te, zwłaszcza w razie niepodejmowania działań przygotowujących do tej sytuacji, staną się zarówno społecznie, jak i ekonomicznie doskwierające. Samorządowcy, w interesie społecznym, powinni, a nawet muszą zainicjować wcześniejsze zainteresowanie przedsiębiorców zaangażowaniem się w srebrną gospodarkę, by uniknąc spowolnienia wzrostu gospodarczego, obniżenia obciążenia ekonomicznego oraz kosztów związanych z opieką zdrowotną i opieką dla osób starszych, gdyż rezultatem wzrostu liczby seniorów jest „,wzrost wydatków publicznych powyżej poziomu możliwego do utrzymania w dłuższym okresie" (Szukalski, 2012, 7).

Aktualnie Leszno podejmuje działania skoncentrowane głównie na bieżącym reagowaniu na zastane skutki związane ze starzeniem się mieszkańców, czyli związane z opieką, rehabilitacją oraz wspieraniem działań NGO-sów, a w nikłym stopniu 
na zapobieganiu zwiększaniu się skali tych skutków. Obecnie ani przedsiębiorcy, ani samorządowcy, ani NGO-sy nie uwzględniają także problemów związanych z zatrudnianiem osób starszych, które to trudności jedynie oni sami zgłaszają, a wydłużenie aktywności zawodowej oraz działania mające na celu wzrost produktywności pracy są rozwiązaniami postulowanymi w celu uniknięcia negatywnych następstw wynikających ze zmian proporcji demograficznych (Miński, Prysłopska, 2019, 151).

Wyniki badań wskazały także na potrzebę przeprowadzenia w przyszłości dalszych badań i nakreśliły ich perspektywę, w której uwzględniony zostanie etap badań ilościowych metodą sondażu diagnostycznego ukierunkowanego na identyfikację potrzeb osób starszych oraz wyodrębnienie czynników różnicujących osoby starsze względem ich potrzeb.

\section{Bibliografia}

Babbie, E. (2008). Podstawy badań społecznych. Warszawa: PWN.

Broszury Urzędu Miasta Leszna „Leszno w liczbach” za lata 2009-2018. Data dostępu: 20.11.2019, https://www.leszno.pl/Dane_o_miescie.html.

Golińska, S. (2014). Srebrna gospodarka - element strategii rozwoju regionalnego. Małopolskie studia regionalne. 2-3/31-32/2014, 17-30.

Gordon, C. (2017). A Silver Econonmy: The value of living longer. Data dostępu: 10.12.2019, https://smartgrowthbop.org.nz/media/2034/silver-economy-report-final-a8179931-compressed-002-a8694352.pdf.

How 21st-Century Longevity Can Create Markets and Drive Economic Growth. A World Economic Forum White Paper. (5.10.2015). Data dostępu: 18.12.2015, http://www3.weforum.org/docs/ WEF_GAC_Ageing_White_Paper.pdf.

Klimczuk, A., (27.05.2013). Srebrna gospodarka jako odpowiedź sektora prywatnego wobec starzenia się spoteczeństwa. Data dostępu: 20.11.2019, http://odpowiedzialnybiznes.pl/artykuly/ srebrna-gospodarka-jako-odpowiedz-sektora-prywatnego-wobec-starzenia-sie-spoleczenstwa.

Kubejko-Polańska, E. (2017). The role of local self-government in stimulating urban development in the context of the construction of age-friendly cities and the concept Silver Economy. Nierówności Społeczne a Wzrost Gospodarczy, 49, 1, 216-227.

Miński, R. (2017). Wywiad pogłębiony jako technika badawcza. Możliwości wykorzystania IDI w badaniach ewaluacyjnych. Przegląd Socjologii Jakościowej. 13, 3, 30-51.

Miński, R., Prysłopska, A. (2019). Senior studies as a response to the phenomenon of aging societies. Gerontologia polska. 27, 150-156.

Raport Ministerstwa Rozwoju Regionalnego i OECD. (2013). Przemiany demograficzne i starzenie sie społeczeństwa: konsekwencje dla lokalnych rynków pracy w Polsce. Data dostępu: 15.12.2019, https://www.efs.2007-2013.gov.pl/analizyraportypodsumowania/documents/zmiany\%20demograficzne_raport\%20oecd_wersja\%20pl.pdf.

Szukalski, P. (2012). Trzy kolory: srebrny. Co to takiego silver economy? Polityka spoleczna. 5-6 (458-459), 6-10.

Ekonomia - Wroclaw Economic Review 26/1, 2020

(C) for this edition by CNS 